\title{
Influence of El Niño/southern oscillation, Pacific decadal oscillation, and local sea-surface temperature anomalies on peak season monsoon precipitation in India
}

\author{
Shouraseni Sen Roy, Gregory B. Goodrich, Robert C. Balling Jr* \\ Department of Geography, Arizona State University, Tempe, Arizona 85287, USA
}

\begin{abstract}
Many modeling and empirical studies have revealed that summer monsoon precipitation in India is significantly affected by El Niño/Southern Oscillation (ENSO) as well as by seasurface temperatures (SSTs) in the Arabian Sea, Bay of Bengal, and Indian Ocean. Recently, the impact of the Pacific decadal oscillation (PDO) on Indian rainfall has been the focus of research. In this investigation, we collect monthly rainfall data for 18 grid cells covering India and develop statistical indices of ENSO, PDO, and local SSTs over the period 1925-1998. We find that ENSO reduces precipitation in southern India while having a small impact over most of the country. The PDO appears to amplify the ENSO signal in southern India, while local SSTs were directly related to monsoon precipitation totals in the southern peninsula region. While the associations are often statistically significant, the combination of ENSO, PDO, and SSTs explains less than $20 \%$ of the variance in monsoon rainfall throughout India.
\end{abstract}

KEY WORDS: India monsoon rainfall · El Niño/Southern Oscillation · Pacific Decadal Oscillation • Sea surface temperatures

\section{INTRODUCTION}

The impact of El Niño/Southern Oscillation (ENSO) on regional climate patterns has been a major theme in climatology for many decades. In the case of India, where rainfall is critical to the large agricultural economy, many scientists have found that El Niño periods reduce precipitation, particularly in the summer monsoon period (Khandekar 1979, Pant \& Parthasarathy 1981, Shukla \& Paolino 1983, Verma 1994, Krishnamurty \& Goswami 2000). Singh (2001) reported that while the ENSO signal could be found throughout India, the relationship is strongest in the northwestern and southern regions of the country. Oppositely, Ropelewski \& Halpert (1989), among others, have noted a clear tendency for greater than normal summer monsoon rainfall during high index phase of ENSO (La Niña), when relatively cold water appears in the eastern tropical Pacific. Recently, Ashrit et al.
(2001) suggested a decrease in the impact of ENSO on the Indian monsoon rainfall as a result of increased concentration of greenhouse gasses. They attributed this decrease in an ENSO signal to enhanced Eurasian warming, stronger monsoon circulation, and shifts in the subsidence patterns associated with the Walker circulation.

The empirical linkage between ENSO and rainfall in India has been reasonably well simulated in various numerical models. Keshavmurty (1982) conducted tests with the GFDL model for $15 \mathrm{yr}$ of simulated time and found that warm anomalies in the central Pacific were associated with weak Indian monsoons. Goswami (1998) used the R30 version of the GFDL model and found decreased precipitation over continental India during periods of El Niño. The decrease in precipitation was attributed to the eastward migration of the ascending branch of the Walker circulation from its usual position over Indonesia to the central Pacific. Lau 
\& Nath (2000) concluded that many modeling studies have shown the dominant influence of the tropical Pacific conditions on the circulation patterns of Asian summer monsoon.

In recent years, climate scientists have turned their attention to climate impacts of the Pacific decadal oscillation (PDO), defined as a long-lived widespread pattern of Pacific climatic variability (Zhang et al. 1997) prevailing over 20 to $30 \mathrm{yr}$ (Mantua et al. 1997, Minobe 1997) as opposed to the much higher interannual variability of ENSO. According to Gershunov \& Barnett (1998), the warm phase of the PDO is complementary to El Niño and tends to create a stronger and more stable climate signal over North America. The cool phase of the PDO similarly enhances the dry La Niña climate signal. A variety of other investigators (McCabe \& Dettinger 1999, Gutzler et al. 2002) have confirmed that the phase of the PDO has significant impact on the precipitation patterns produced by the ENSO climate signal. In the case of India, Krishnan \& Sugi (2003) found that over the period 1871-2002 a warm (cool) phase of the PDO was related to a decrease (increase) in an 'all India summer monsoon rainfall' index based on 306 stations. Their results confirmed suggestions by others that the PDO would amplify regional climate signals related to ENSO.

While monsoon precipitation throughout India is related to ENSO and PDO, the rainfall is also related to the sea-surface temperatures (SSTs) of the Indian Ocean, Arabian Sea, and Bay of Bengal. Shukla (1975) used a fairly simple numerical model and found that cold SSTs in the Arabian Sea would reduce evaporation, increase surface pressure downstream, and therefore reduce monsoon rainfall over India. Washington et al. (1977) attempted to reproduce the simulations of Shukla and reported little if any effect of local SSTs on monsoon rainfall. Weare (1979) used an empirical approach involving principal component analysis (PCA) and found that SSTs in the Arabian Sea and Indian Ocean over the period 1949-1972 were negatively, but weakly, related to monsoon precipitation throughout most of India. Rao \& Goswami (1988) examined ship records from 1900-1979 and found that warmer SSTs in the southern portion of the Arabian Sea tended to generally increase monsoon rainfall; similar findings were reported by Ramesh Kumar \& Sastry (1990) and Hastenrath \& Greishar (1993). Ramesh Kumar et al. (1999) found that monsoon rainfall in India was positively related to SSTs in the central Indian Ocean during the period 1988-1992. However, Krishnan et al. (2003) used a numerical model and found that warm SSTs in the Indian Ocean enhanced rainfall activity near the Equator, but reduced precipitation over the sub-continent. It is noteworthy that the earlier modeling studies of the 1970s indicated a weak relation between the SSTs and the Indian monsoon rainfall, while more recent modeling studies show a positive relation between these 2 variables.

Several investigators (Andersen 1999, Saji et al. 1999) have analyzed the bipolar mode of SSTs in the Indian Ocean with respect to rainfall in the region. While strong signals have been reported for precipitation in East Africa and Indonesia, there appears to be no clear relationship between the Indian Ocean dipolar mode and the India monsoon rainfalls.

Given the well-documented strong ENSO impact on Indian precipitation, the recently discovered amplifying effect of PDO, and the ongoing debate regarding the role of local SSTs on Indian rainfall, we have conducted a series of analyses that can reveal the independent effects of these forcings on the summer monsoon precipitation. We also investigated how the strength of correlations between ENSO and precipitation change depending on the phase of the PDO. Our analyses revealed regional differences in how ENSO, PDO, and SSTs influence the summer monsoon rainfall; we also determined how well these 3 forcings can distinguish between the wettest and driest years in different parts of India.

\section{DATABASES}

Hulme (1992) developed and made available a gridded, $5^{\circ}$ resolution database consisting of monthly precipitation for global land areas from 1900 to 1998; the details of the database construction are available in Hulme (1995) and New et al. (2000). India is covered by 18 of the $5^{\circ}$ latitude by $5^{\circ}$ longitude gridcells, and we found that for these cells the number of missing monthly entries increases rapidly at times earlier than 1925. Therefore, we selected $1925-1998$ as our study period. Furthermore, we selected July and August as our summer monsoon season months, despite the fact that June-September is taken as the summer monsoon season in India. However, the entire country comes under the grip of monsoon only during July and August, while in June and September, the country is only partially covered by the monsoon. Since July and August are the rainiest months, they largely determine the overall performance of the monsoon season, and any teleconnection signal can be expected to be the most prominent during this period. Over the $74 \mathrm{yr}$ study period and 18 grid cells, only $0.8 \%$ of the data were missing for the 2 summer monsoon months.

We assembled 2 different variables to characterize ENSO over the period 1925-1998. Although many highly intercorrelated variables are available to characterize the Southern Oscillation, we selected a July time series based on the difference between standard- 
ized sea-level pressures at Tahiti and Darwin, with the resultant time series of differences then being standardized. Large negative values indicate periods of El Niño, while large positive values indicate periods of La Niña. The 1927 and 1932 values were missing in the summer season matrix.

While the SOI is determined by atmospheric circulation, we used a second indicator of ENSO based on July SSTs. Trenberth (1997) determined that the SSTs in an area bounded by $5^{\circ} \mathrm{N}$ to $5^{\circ} \mathrm{S}$ and 90 to $150^{\circ} \mathrm{W}$ are particularly good indicators of ENSO, and accordingly, we selected the SST anomalies (based on a 1950-1979 normal period) for that region; there are no missing data in the SST times series.

The PDO characterizes low-frequency changes in the Pacific Ocean with a period of approximately $50 \mathrm{yr}$. The PDO index is the leading principal component or eigenvector of the mean monthly SSTs in the Pacific Ocean north of $20^{\circ} \mathrm{N}$ (Mantua et al. 1997). Positive values of the index refer to above-normal SSTs along the west coast of North America and along the equator and below-normal SSTs in the central and western North Pacific around $45^{\circ} \mathrm{N}$. During the past century, there have been only 2 complete cycles of the PDO (Mantua \& Hare 2002). Cool phases of the PDO have persisted from 1890-1924 and from 1947-1976, while warm phases persisted from 1925-1946 and from 1977 through at least the late 1990s. Since several researchers (Hare \& Mantua 2000, Schwing \& Moore 2000) have shown there may have been a phase change at the completion of the 1997-98 El Niño, we will end the most recent warm phase at 1997 and denote 1998 as cool. Whether or not 1998 represents the beginning of a multidecadal cool phase will not be known for some time. For this study, we have used 0 for cool years and 1 for warm years of the PDO.

Finally, we collected the July SST anomalies from the widely used Jones et al. (1999) temperature times series for forty-four $5^{\circ}$ latitude by $5^{\circ}$ longitude grid cells in the Indian Ocean, Arabian Sea, and Bay of Bengal. The cells range latitudinally from $5^{\circ} \mathrm{S}$ to $25^{\circ} \mathrm{N}$ and longitudinally from 50 to $95^{\circ} \mathrm{E}$. We found that 28 of these cells had no missing data over 1925-1998. Because most of our cells are over water, the data in the Jones et al. time series for our study area would come from a combination of highly related SSTs and marine air temperatures.

\section{ANALYSES AND RESULTS}

Given our intention of using a combination of multivariate techniques to determine the linkage between rainfall in India and PDO, ENSO, and SSTs, we first examined all data for normality (a Gaussian distribution) using standardized coefficients of skewness and kurtosis as well as the Kolmogorov-Smirnov 1-sample test of normality. Our results showed that 3 of the 18 precipitation time series in July-August were confirmed as having a significant deviation from normality (based on the 0.01 level of confidence). In almost every case, the deviation from the Gaussian distribution was related to a few large rainfall values that produced a positive skewness in the array. We found that a squareroot transformation eliminated or largely reduced the significant deviation from normality. We also found that our fundamental results changed little whether we used transformed or untransformed precipitation time series.

Recognizing that our 2 ENSO-related variables are highly correlated, we chose PCA to re-write these variables onto 1 axis. We found that one eigenvector explained $81 \%$ of the variance in the 2 variables with a loading of 0.90 on the SST time series from the area bounded by $5^{\circ} \mathrm{N}$ to $5^{\circ} \mathrm{S}$ and 90 to $150^{\circ} \mathrm{W}$ and a loading of -0.90 on the SOI variable defined by pressure differences between Tahiti and Darwin. The resulting component scores (Fig. 1) show considerable variability

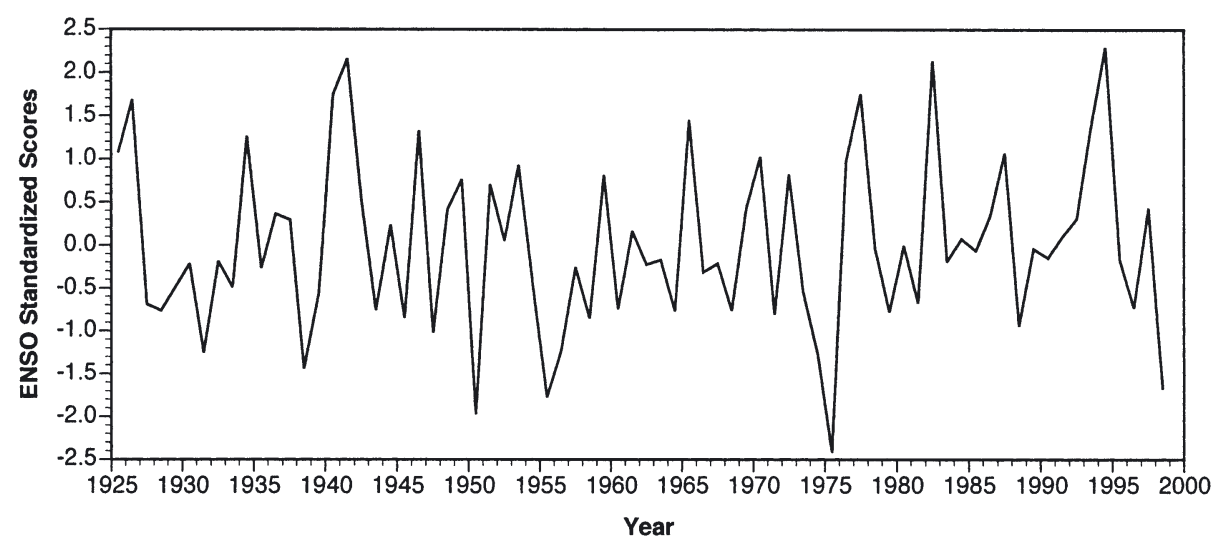

Fig. 1. Time series plot of July ENSO component scores over the period 1925-1998 


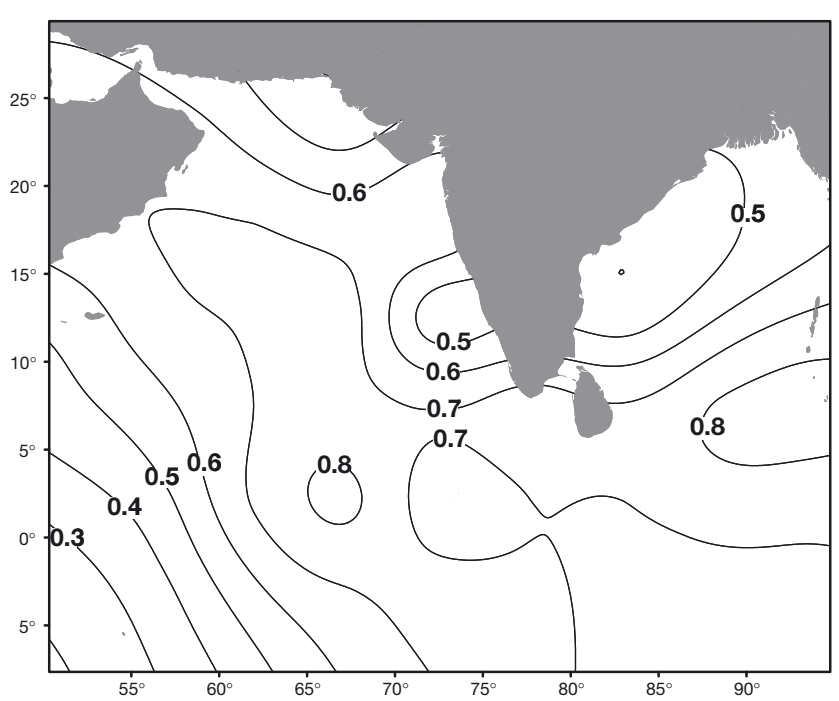

Fig. 2. Loadings for the first component based on sea-surface temperature (SST) data

from year to year, effectively no trend $(r=-0.03)$ and no first-order autocorrelation $(\mathrm{r}=0.01)$.

We next used PCA to condense variance in the Indian Ocean, Arabian Sea, and Bay of Bengal SST matrix containing the 28 cells without missing data. We found that one eigenvector explained $44.3 \%$ of the variance in the matrix and had relatively high loadings on cells surrounding the subcontinent (Fig. 2). There was a general increase in the eigenvector values towards the center of the Indian Ocean south of the Indian peninsula. A plot of the component scores (Fig. 3) reveals a significant upward trend $(r=0.49)$ and a first-order autocorrelation coefficient of 0.36 . The subsequent components explained less than $8 \%$ of the overall SST variance each and ultimately did not share significant variance with regional precipitation variations in India.
Somewhat surprisingly, we found relatively low correlation coefficients between our ENSO component and PDO ( $\mathrm{r}=0.24)$, the ENSO component and the SST component $(\mathrm{r}=0.28)$, and the SST component and PDO $(r=0.25)$. Since no two of these variables share as much as $8 \%$ of their variance, they represent nearly independent predictors of monsoon precipitation in India.

The 3 ENSO, PDO, and SST time series became the independent variables in a set of multiple regression analyses, while the July-August rainfall data from the 18 grid cells served as the dependent variables. The standardized regression coefficients reveal the sign and relative importance of ENSO, PDO, and SSTs in controlling monsoon season precipitation throughout India. We used the spline interpolation method to generate isopleth maps of the standardized regression coefficients and multiple $\mathrm{R}$ values. This technique isolates regional patterns in the strength and sign of the coefficients, but the smoothing tends to reduce the absolute value of the larger standardized regression coefficients.

We found that the ENSO signal in monsoon rainfall was significant and negative in 3 of the 18 grid cells; 2 cells met the 0.01 level of confidence while the other could only meet the 0.05 level. As seen in Fig. 4, the ENSO component has a significant and negative impact on monsoon precipitation throughout southern India indicating that El Niño years are generally associated with low monsoon rainfall. The positive correlation between ENSO and the monsoon rainfall was located only over the eastern part of the Gangetic plain stretching across the Chota Nagpur plateau to coastal Orissa. The impact of ENSO on precipitation over the rest of the subcontinent covering the northwestern Himalayas to the Deccan plateau in the south was negative. ENSO had a negative forcing on some of the rainiest regions of the country located in the northeast and the entire west

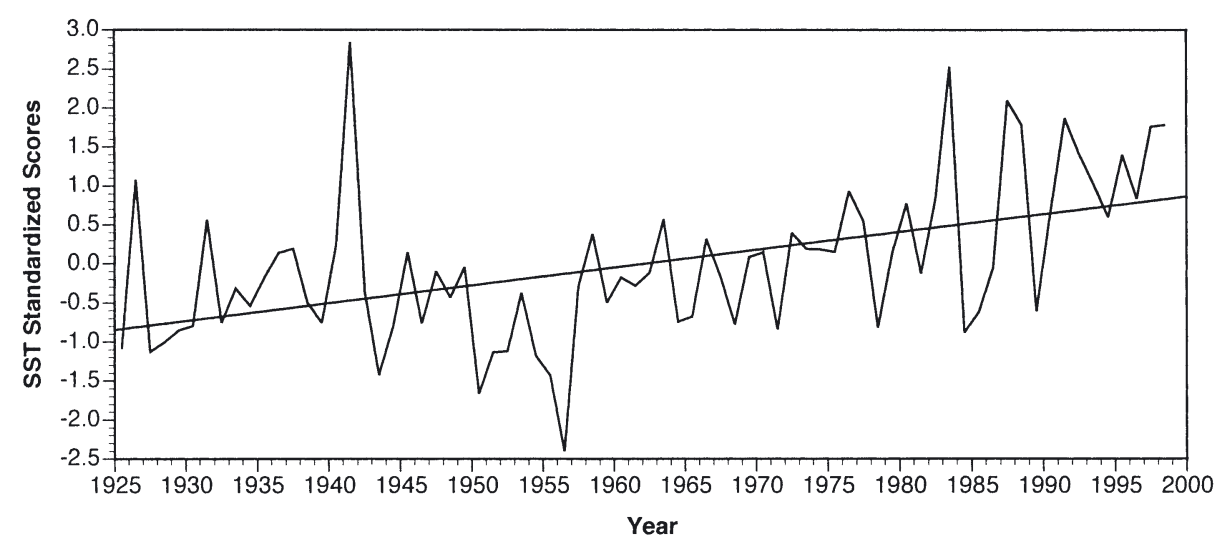

Fig. 3. Time series plot of July SST component scores over the period 1925-1998 


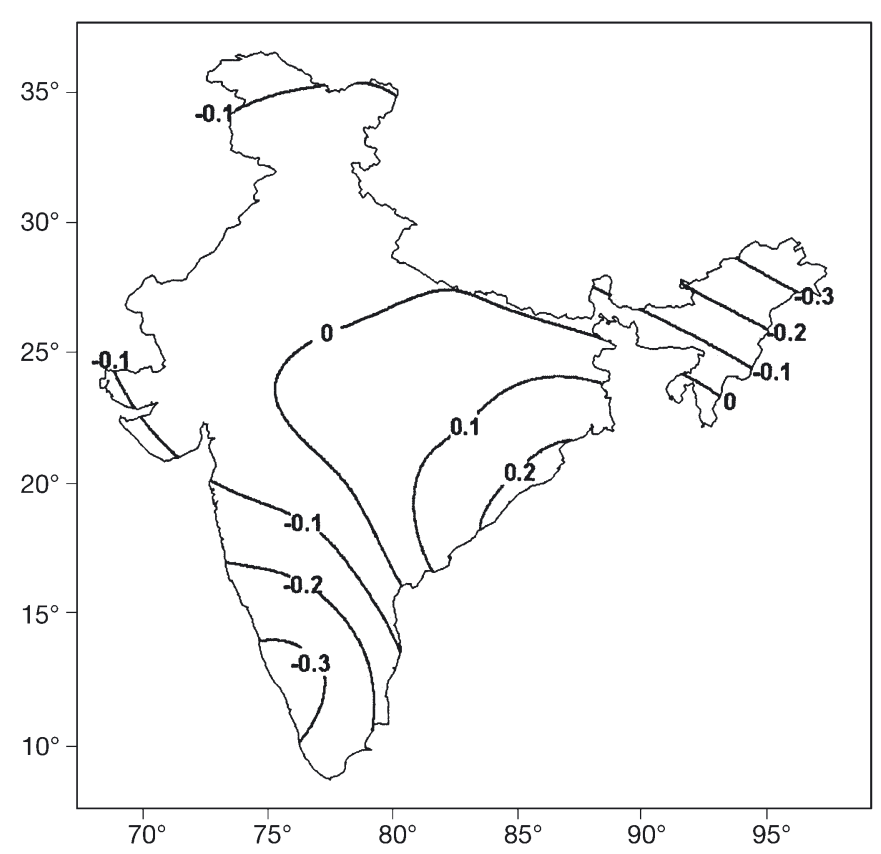

Fig. 4. Standardized regression coefficients showing the strength of the relationship between ENSO and July-August precipitation (absolute values $>0.22$ are significant at the 0.05 level of confidence)

coast. Our findings are consistent with those of Singh (2001), indicating negative impact of ENSO on the precipitation patterns over northwestern part of India and the peninsular region. However, throughout most of India, the ENSO signal is weak and far from statistically significant.

The PDO signal was significant at 5 of the grid cells ( 2 at the 0.01 level of confidence and 3 at the 0.05 level), and in each case, the sign of the regression coefficient indicates a negative association between PDO and rainfall in India. Fig. 5 reveals that PDO is negatively related to rainfall in most of the Indian mainland, indicating that warm phases of PDO reduce monsoon precipitation. The spatial effect of PDO was found to be very similar to that of ENSO over the subcontinent. The effect of PDO was positive over the eastern part of the Gangetic plain and Chota Nagpur plateau extending to coastal Orissa. The entire Deccan plateau was negatively related to PDO, with the most significant region located in the western coast. Another region of negative correlations is located over the northwestern plains in western Uttar Pradesh, Rajasthan, Haryana and Punjab stretching to the foothills of the Himalayas.

Three grid cells have a positive association between rainfall and the SST component that is significant at the 0.01 level of confidence, while 3 grid cells have a negative relation between the two that is significant at the 0.05 level. The effect of the SSTs on the summer rainfall in India is generally opposite when compared to the impact of ENSO and PDO. Fig. 6 shows that warm SSTs tend to enhance rainfall in the Deccan plateau and the northeastern states of India. The most significant associations are located over the peninsular region in the Malabar Coast covering the eastern coastal states of Kerala, Karnataka, and parts of Maharashtra. However, the effect of SSTs is negative on the rainfall occurring in the entire northern plains, including the Himalayas in the north. Our results are consistent with the findings of Ramesh Kumar et al. (1999) suggesting the negative correlation between Indian Ocean SST anomalies and the monsoon rainfall in parts of central and western India.

The coefficient of determination values (multiple $\mathrm{R}$ values) for the 18 multiple regression equations ranged from 0.08 to 0.46 with 4 values significant at the 0.01 level of confidence and 1 significant at the 0.05 level (the values can be squared to determine the amount of variance explained in the rainfall data). Fig. 7 shows that the combination of ENSO, PDO, and SSTs generates the highest explained variance in the Deccan states of Kerala, Tamilnadu, Karnataka, and parts of Maharashtra. The variance is also high in the northeastern part of the subcontinent. The least explained

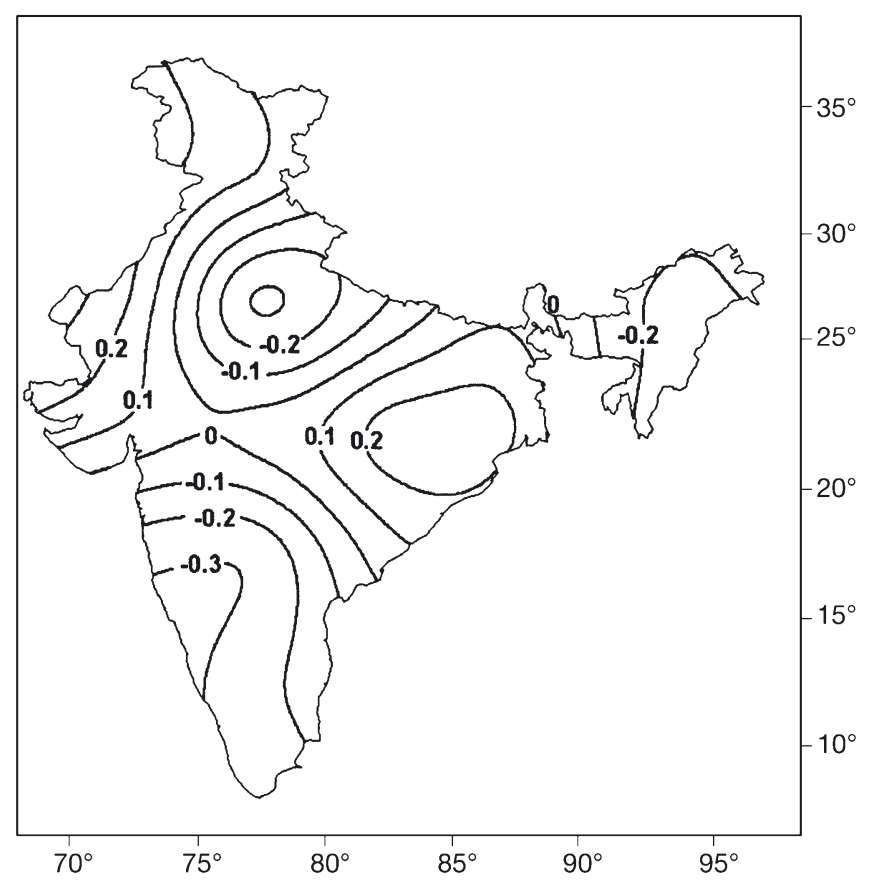

Fig. 5. Standardized regression coefficients showing the strength of the relationship between PDO and July-August precipitation 


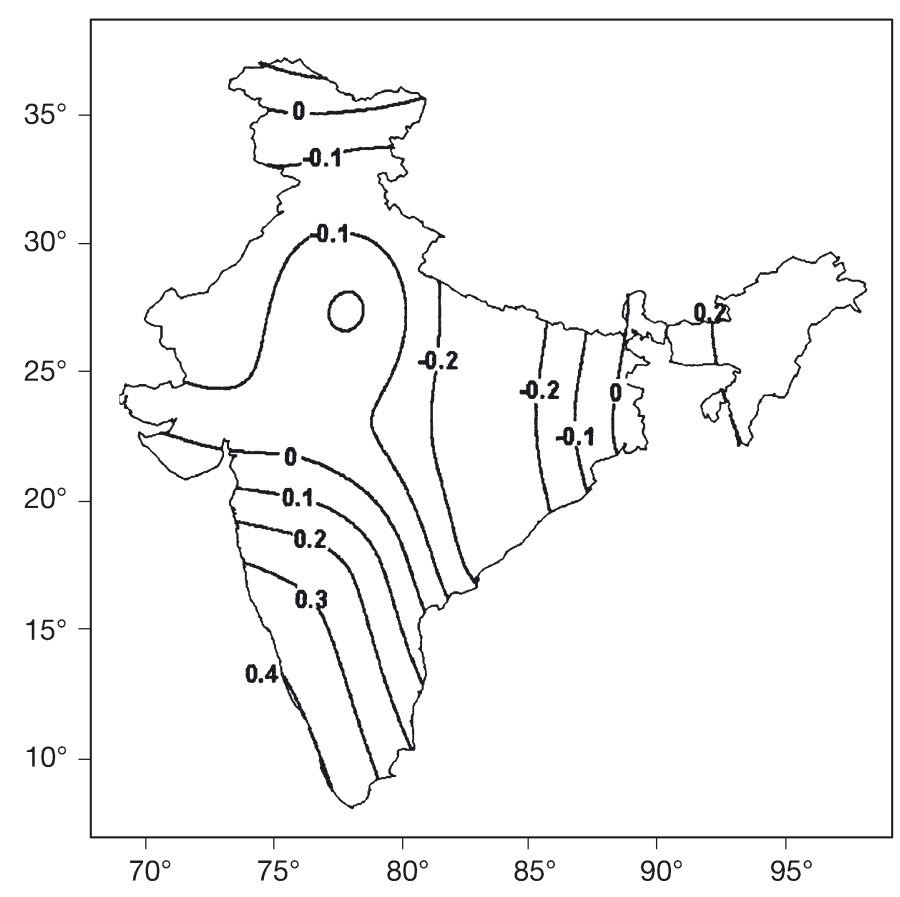

Fig. 6. Standardized regression coefficients showing the strength of the relationship between the SST component and July-August precipitation

variance was observed in the central and western part of the mainland over parts of Maharashtra, Madhya Pradesh, and Gujarat.

In addition to determining the correlations between ENSO and PDO against Indian monsoon rainfall separately, we examined the correlations between ENSO and Indian monsoon rainfall by the warm and cold phases of the PDO. Correlation coefficients during the cold phase of the PDO are stronger than those during the warm phase in 11 of 18 grid points. Furthermore, 3 of these 11 differences in correlation coefficients were determined to be significant using a statistical test suggested by Kleinbaum \& Kupper (1978). The 3 grid points extend from the foothills of the Himalayas to the northern part of the Deccan plateau. This change in correlation by phase of the PDO suggests that forecasts based on the ENSO climate signal may have more success in southern India during the cold phase of the PDO.

Finally, we used multiple discriminant analysis to determine how well the 3 independent variables discriminate the 25 wettest years from the 25 driest years at each of the 18 grid cells. We found that the reclassification ability of the discriminant functions (1 function for each grid cell) ranged from 54.3 to $76.1 \%$. As seen in Fig. 8, the accuracy of the functions was highly related $(r=0.89)$ to the multiple $R$ values from the regression analyses.

\section{CONCLUSIONS}

Our analysis of ENSO, PDO, SSTs, and seasonal precipitation in India showed the following:

(1) In southern India, we found a negative association between an ENSO component and monsoon rainfall. These results are consistent with the findings of Singh (2001). Throughout much of India, the association between rainfall and our ENSO component did not appear to be statistically significant. It is likely that the warm phase of ENSO promotes an eastward migration of the ascending branch of the Walker circulation, thereby reducing convection in India during the monsoon season (Caviedes 2001).

(2) Throughout central and southern India, PDO is negatively related to precipitation with the warm phase of PDO lowering monsoon rainfall. In several grid cells located mainly in the peninsular India, both PDO and ENSO were significant determinants of rainfall levels, suggesting that the PDO can amplify ENSO signals in India. This result is consistent with the recent findings of Krishnan \& Sugi (2003) that India is more vulnerable to drought situations when an El Niño event occurs during the warm phase of PDO. While the dynamics of how the warm phase of the PDO may enhance El Niño are not clear, it is likely that the PDO strengthens the eastward migration of the ascending branch of the Walker circulation associated with El Niño conditions, thereby reducing convection over

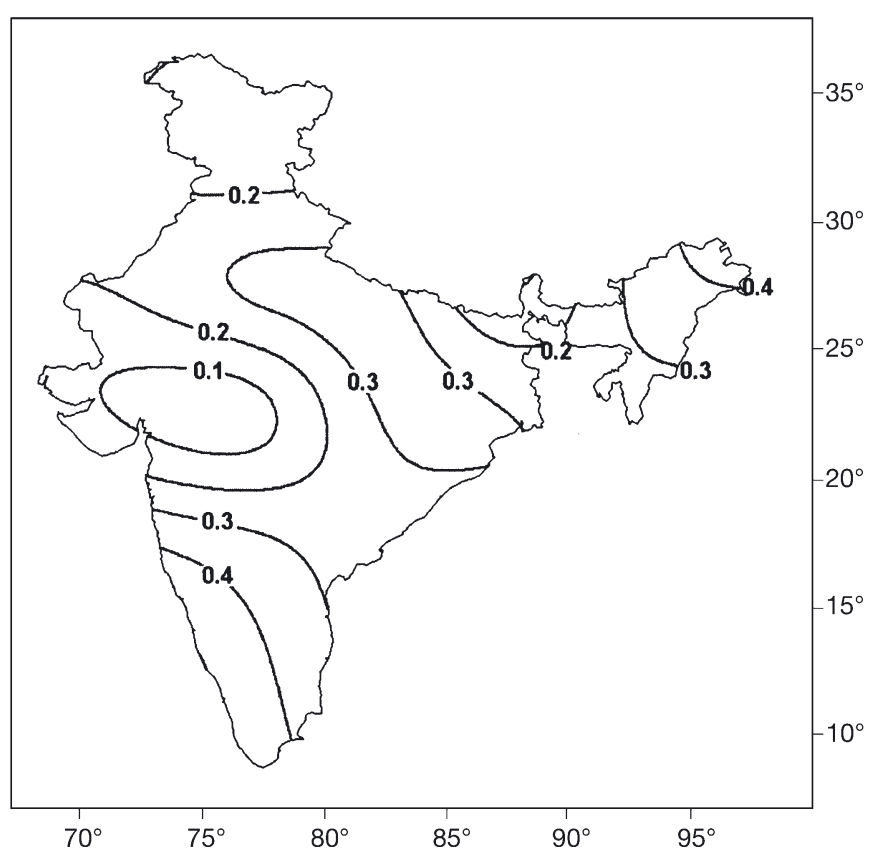

Fig. 7. Multiple $\mathrm{R}$ values associated with the 18 multiple regression equations 


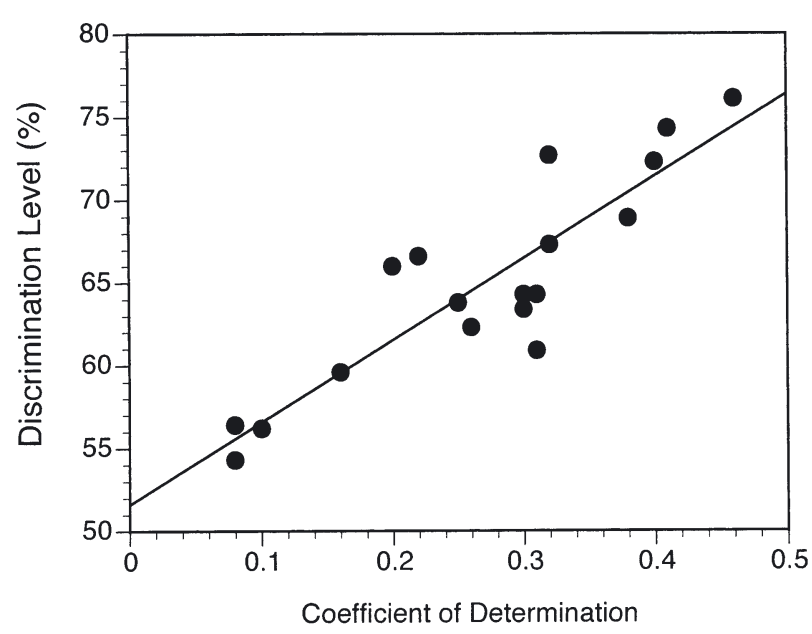

Fig. 8. Relation between the accuracy of the discriminant functions and the coefficient of determination (multiple $\mathrm{R}$ values) from the $18 \mathrm{grid}$ cells

India during the monsoon season. The shift in the Walker circulation inhibits the ascent of air over Indian subcontinent, resulting in the creation of high pressure and reduced cloud formation.

(3) SSTs in the Arabian Sea, Indian Ocean, and Bay of Bengal were positively related to rainfall in southern India and weakly related to the rainfall in other regions of the subcontinent. Many others (Shukla \& Mishra 1977, Ramesh Kumar et al. 1999) have found similar results about the significant role of the SST anomalies over the Indian Ocean, the Arabian Sea and the Bay of Bengal. These studies point out the importance of the moisture budget and the amount of evaporation taking place in these seas as a determinant of the amount of precipitation taking place in different parts of the country.

(4) The overall association of ENSO, PDO, and the SSTs to the rainfall patterns in different parts of the country show broadly similar patterns. Both ENSO and PDO have a significant negative forcing on the rainfall in the peninsular region centered on the southeast coast and the northeastern region. On the other hand, the SST component exerts a positive influence on the rainfall in these 2 regions. The onset of the monsoon for these 2 regions is within the first $2 \mathrm{wk}$ of the month of June; these are also the regions receiving heaviest rainfall in the country due to favorable relief and location. Therefore, it can be said that the warm phase of PDO amplifies the effect of ENSO on Indian summer precipitation in the regions with heaviest rainfall.

(5) While our 3 independent variables had statistically significant relationships with the July and August rainfall totals, their predictive power could explain little more than $20 \%$ of the variance in the rainfall time series. Furthermore, in the best examples, the discrim- inant functions could reclassify dry or wet years with $75 \%$ accuracy.

Many other investigators have analyzed spatial and temporal patterns in monsoon precipitation throughout India. Despite different databases, periods of record, and methodologies, the underlying spatial patterns and relationships clearly revealed in our investigation reinforced the findings of many others. However, our approach allowed the independent effects of ENSO, SSTs, and PDO to be revealed spatially in the monsoon rainfall of India.

\section{LITERATURE CITED}

Andersen D (1999) Climatology: extremes in the Indian Ocean. Nature 401:337-338

Ashrit RG, Rupa Kumar, K, Krishna Kumar, K (2001) ENSOMonsoon relationship in greenhouse warming scenario. Geophys Res Lett 28:1727-1730

Caviedes CN (2001) El Niño in history: storming through the ages. University Press of Florida, Gaineville, FL

Gershunov A, Barnett TP (1998) Interdecadal modulation of ENSO teleconnections. Bull Am Meteorol Soc 79: 2715-2725

Goswami BN (1998) Interannual variations of Indian summer monsoon in a GCM: external conditions versus internal feedbacks. J Clim 11:501-522

Gutzler DS, Kann DM, Thornbrugh C (2002) Modulation of ENSO-based long-lead outlooks of Southwestern US winter precipitation by the Pacific Decadal Oscillation. Weather Forecast 17:1163-1172

Hare SR, Mantua NJ (2000) Empirical evidence for North Pacific regime shifts in 1977 and 1989. Prog Oceanogr 47: 103-146

Hastenrath S, Greischar L (1993) Changing predictability of Indian monsoon rainfall anomalies? Proc Ind Acad Sci Earth Planet Sci 102:35-47

Hulme M (1992) A 1951-80 global land precipitation climatology for the evaluation of General Circulation Models. Clim Dyn 7:57-72

Hulme M (1995) Estimating global changes in precipitation. Weather 50:34-42

Jones PD, New M, Parker DE, Martin S, Rigor IG (1999) Surface air temperature and its changes over the past 150 years. Rev Geophys 37:173-199

Keshavmurty RN (1982) Response of the atmosphere to seasurface temperatures anomalies over the equatorial Pacific and the teleconnections of the Southern Oscillation. J Atmos Sci 39:1241-1259

Khandekar ML (1979) Climatic teleconnections from the equatorial Pacific to the Indian monsoon, analysis and implications. Arch Meteorol Geophys Bioklim 28:159-168

Kleinbaum DG, Kupper LL (1978) Applied regression analysis and other multivariate methods. Duxbury Press, North Scituate, MA

Krishnamurthy V, Goswami BN (2000) Indian monsoon-ENSO relationship on interdecadal timescale. J Clim 13: 579-595

Krishnan R, Sugi M (2003) Pacific decadal oscillation and variability of the Indian summer monsoon rainfall. Clim Dyn 21:233-242

Krishnan R, Mujumdar M, Vaidya V, Ramesh KV, Satyan V (2003) The abnormal Indian summer monsoon of 2000 . J Clim 16:1177-1194 
Lau NC, Nath MJ (2000) Impact of ENSO on the variability of the Asian-Australian monsoons as simulated in GCM experiments. J Clim 13:4287-4309

Mantua NJ, Hare SR (2002) The Pacific Decadal Oscillation. J Oceanogr 58:35-44

Mantua NJ, Hare SR, Zhang Y, Wallace JM, Francis RC (1997) A Pacific interdecadal climate oscillation with impacts on salmon production. Bull Am Meteorol Soc 78:1069-1079

McCabe GJ, Dettinger MD (1999) Decadal variations in the strength of ENSO teleconnections with precipitation in the western United States. Int J Climatol 19:1399-1410

Minobe S (1997) A 50-70 year climatic oscillation over the North Pacific and North America. Geophys Res Lett 24: 683-686

New MG, Hulme M, Jones PD (2000) Representing twentiethcentury space-time climate variability. Part II: Development of 1901-1996 monthly grids of terrestrial surface climate. J Clim 13:2217-2238

Pant GB, Parthasarathy B (1981) Some aspects of an association between the Southern Oscillation and Indian summer monsoon. Arch Meteorol Geophys Bioklim 29:245-251

Ramesh Kumar MR, Sastry JS (1990) Relationship between sea surface temperature, Southern Oscillation, position of the $500 \mathrm{mb}$ ridge along $75^{\circ} \mathrm{E}$ in April and the Indian monsoon rainfall. J Meteorol Soc Jpn 68:741-745

Ramesh Kumar MR, Muraleedharan PM, Sathe PV (1999) On the role of sea surface temperature variability over the tropical Indian Ocean in relation to summer monsoon using satellite data. Remote Sensing Environ 70:238-244

Rao KG, Goswami BN (1988) Interannual variations of SST over the Arabian Sea and the Indian monsoon: a new perspective. Mon Weather Rev 116:307-312

Ropelewski CF, Halpert MS (1989) Precipitation patterns associated with the high index phase of the Southern

Editorial responsibility: Chris de Freitas, Auckland, New Zealand
Oscillation. J Clim 2:268-284

Saji NH, Goswami BN, Vinayachandran PN, Yamagata T (1999) A dipole in the tropical Indian Ocean. Nature 401: 360-363

Schwing F, Moore C (2000) A year without a summer for California, or a harbinger of a climate shift? EOS Trans Am Geophys Union 81:301,304-305

Shukla J (1975) Effect of Arabian Sea surface temperature anomaly on Indian summer monsoon: a numerical experiment with GFDL model. J Atmos Sci 32:503-511

Shukla J, Mishra BM (1977) Relationships between sea surface temperature and wind speed over the central Arabian Sea and monsoon rainfall over India. Mon Weather Rev 105:998-1002

Shukla J, Paolino JA (1983) The Southern Oscillation and the long range forecasting of summer monsoon rainfall over India. Mon Weather Rev 111:1830-1853

Singh OP (2001) Multivariate ENSO index and Indian monsoon rainfall: relationships on monthly and subdivisional scales. Meteorol Atmos Phys 78:1-9

Trenberth KE (1997) The definition of El Niño. Bull Am Meteorol Soc 78:2771-2777

Verma RK (1994) Variability of Indian summer monsoon: Relationship with global SST anomalies. Mausam 45: 205-212

Washington W, Chervin R, Rao, GV (1977) Effects of a variety of Indian Ocean surface temperature anomaly patterns on the summer monsoon circulation: experiments with the NCAR GCM. Pure Appl Geophys 115.1335-1356

Weare BC (1979) A statistical study of the relationships between ocean surface temperatures and the Indian monsoon. J Atmos Sci 36:2279-2291

Zhang Y, Wallace JM, Battisti DS (1997) ENSO-like interdecadal variability: 1900-93. J Clim 10:1004-1020

Submitted: June 25, 2003; Accepted: October 17, 2003

Proofs received from author(s): November 26, 2003 